\title{
PREVALENCE, CLINICAL AND LABORATORY CHARACTERISTICS OF KIDNEY DISEASE IN ANTIRETROVIRAL NAÏVE HIV INFECTED PATIENTS IN SOUTH-SOUTH NIGERIA
}

\author{
Okafor $\mathrm{UH}^{1}$, Unuigbe $\mathrm{EI}^{2}$, Chukwuonye $\mathrm{E}^{3}$
}

1. Renal Unit, Department of Medicine, Enugu State University Teaching Hospital, Parklane Enugu

2. Renal Unit, Department of Medicine, University of Benin Teaching Hospital, Benin City

3. Renal Unit, Department of Medicine, Federal Medical Centre, Umuahia

\begin{abstract}
\section{BACKGROUND}

Since the emergence of acquired immune deficiency syndrome (AIDS) about three decades ago, several renal disorders have been reported as common complications of the human immunodeficiency virus (HIV) infection. These renal disorders have resulted from diverse aetiologies. The aim of this study was to determine the prevalence, clinical and laboratory characteristics of antiretroviral naïve HIV-infected patients with impaired kidney disorder in South-South Nigeria.
\end{abstract}

\section{METHODS}

This was a cross-sectional study of antiretroviral naïve HIV-infected patients presenting at the University of Benin Teaching Hospital (UBTH), Benin City in South-South Nigeria for six months. The patients' biodata, clinical, haematological and biochemical parameters were assessed. Their glomerular filtration rate using the six equation of MDRD and protein excretion was calculated from protein-creatinine ratio. Data was analysed using statistical software program SPSS version 15.0.

\section{RESULTS}

Three hundred and eighty-three (383) patients with a mean age of $35.39 \pm 8.78$ years with a male/female ratio of 1:1were studied. Of these $53.3 \%$ had evidence of kidney disorder. The main clinical features in patients with kidney disorder were evidence of fluid retention, urinary symptoms, pallor and encephalopathy. The mean systolic and diastolic blood pressure was $115.33 \pm 17.17$ and $72.33 \pm 14.31 \mathrm{mmHg}$ respectively. The mean estimated glomerular filtration rate (eGFR) was $52.5 \mathrm{ml} /$ minute $/ 1.73 \mathrm{~mm}^{2}$

Patients with kidney disorder had worse proteinuria $(\mathrm{p}=0.001)$, lower mean CD4 cell count, and packed cell volume ( $p=0.019$ and 0.001 respectively).

\section{CONCLUSION}

Kidney disorder is a common complication in HIV-infected patients and they have clinical and laboratory anomalies. Screening of HIV/AIDS patients at point of diagnosis will facilitate early diagnosis of kidney disorders in them.

CORRESPONDING AUTROR: Dr Okafor Umezurike Hughes, Renal Unit, Department of Medicine, Enugu State University Teaching Hospital, Parklane Enugu, Nigeria, E-mail: umehughes@yahoo.com 


\section{KEY WORDS}

HIV infection, treatment naïve, impaired kidney function.

\section{INTRODUCTION}

Multiple organs, including the kidneys, are common targets in HIV infection. A variety of renal syndromes have been reported during the course of HIV infection ${ }^{1}$. These present as acute, chronic or acute on chronic kidney disorders.

Rao et $\mathrm{al}^{2}$ first reported in 1984 that renal lesions were found in HIV-infected patients. He went further to describe a glomerulopathy, which was characterised by heavy proteinuria, biochemical features of nephrotic syndrome and azotaemia, which rapidly progressed to end-stage renal disease (ESRD). Since then many types of renal disorders have been encountered ranging from mild transient renal impairment to ESRD. These renal disorders can occur at all stages of HIV infection. ${ }^{3-4}$

Furthermore, kidney disorder can also result from opportunistic infections, toxicity from antiretroviral therapy, as well as other drugs used to manage HIV infection ${ }^{5,6}$. Patients with HIV infection may also develop renal disorder not related to the HIV infection, its consequences or treatment.

The actual global incidence and prevalence of renal disease in HIV infection is not known, thus rendering epidemiologic assessment difficult. In Africa - where the majority of patients with HIV infection live - data regarding renal involvement is scarce. However, the prevalence of renal disease in HIV/AIDS patients has been variously reported to be between $30-60 \%$. ${ }^{1,3,7}$

Most of the renal manifestations of HIV-infected patients represent complications of concurrent infection in a severely immuno-compromised host or side effects of the plethora of treatment required to manage them. ${ }^{8-10}$

Definition of the precise role of the HIV virion and its gene products in instigating pathology within the nephron has been difficult, and most of the proposed pathogenetic mechanisms remain controversial. Attempts to define the pathogenesis of HIV-driven renal disease, including in vivo and in vitro studies of HIV infection in various cell components of the nephron, have not produced a consensus mechanism. ${ }^{11}$

The virus has been reported to affect the kidneys directly causing various glomerular and interstitial kidney diseases. This it achieves by attacking the glomerular epithelial and renal tubular cells. ' Diabetic nephropathy, hypertensive nephrosclerosis, malignant hypertension, chronic glomerulonephritis, lupus nephritis, and chronic pyelonephritis, had been variously reported in HIV-infected patients. ${ }^{33,39,5612-14}$

Early detection and intervention in HIV patients with renal disorder may delay the progression or reverse the impairment in renal function. ${ }^{9,10}$

The aim of this study was to determine the prevalence, clinical and laboratory characteristics of antiretroviral naïve HIV-infected patients with kidney disorder presenting at a tertiary hospital in South-South Nigeria.

\section{SUBJECTS AND METHODS}

This was a cross-sectional study of antiretroviral naïve HIV-infected patients presenting at the University of Benin Teaching Hospital (UBTH) in Benin City, a tertiary healthcare centre in South-South Nigeria. The study was over a six-month period.

Adult HIV-seropositive patients presenting during the study period were recruited for the study after informed consent. However, patients with diabetes mellitus, hypertension, congestive cardiac failure, sickle cell anaemia, malignancies not related to HIV infection, urinary tract infection, and history of renal disease were excluded from the study. Pregnant patients and those on antiretroviral therapy were also excluded.

Consecutive antiretroviral naïve HIV-infected patients presenting in the accident/emergency unit or admitted into the medical wards within the study period and who met the eligibility criteria were recruited for the study.

Ethical clearance from the Ethical and Research Committee of the hospital was obtained. The details of the study, including collection of urine and blood specimens, were explained to all patients participating in the study, and signed consent obtained from each patient before proceeding with the study.

The demographic data and the clinical details of each patient were documented. Blood specimens were collected for assessment of packed cell volume (PCV), serum electrolytes, urea and creatinine. A spot urine sample was collected for assessment of protein and creatinine.

The glomerular filtration rate was calculated using the six formula equation of Modification of Diet in Renal Disease (MDRD), and the urine protein excretion was calculated using the urine protein-creatinine ratio (PCR).

Kidney disorder was defined as impairment in kidney function, detected when the eGFR is $<60 \mathrm{ml} /$ minute $/ 1.73 \mathrm{~m}^{2}$ and/or evidence of kidney injury as detected when the PCR $(\mathrm{mg} / \mathrm{g}) \geq 200$.

The data obtained was entered into a Microsoft Excel electronic spreadsheet and analysed using the SPSS version 
15.0 statistical package. Distributions of variables and defining criteria for kidney disorder were computed. The student's test and chi-square test were used to compare means and proportions of variables respectively. P value less than 0.05 was considered significant.

\section{RESULTS}

Three hundred and eighty-three (383) eligible HIV-infected patients were recruited for the study and of these 204 patients $(53.3 \%)$ had evidence of kidney disorder as defined above.

\section{BIODATA}

Patients studied were aged between 18 and 81years with a mean age of $36.03 \pm 9.08$ years. The mean age of patients with normal and impaired renal function were $35.39 \pm 8.78$ years and $36.67 \pm 9.38$ years respectively $(p=0.66)$.

Table 1 shows the age distribution of the patients according to renal function. The majority $(89.8 \%)$ of patients were younger than 50 years. HIV infection and impaired kidney function (IKF) were commonest in the 30-39 years age group.

Sex distribution of patients studied according to kidney function is shown in Figure 1. Females made up 58.5\% of the study population. Normal kidney function (NKF) was demonstrated in $67.5 \%$ and $32.5 \%$ of females and males respectively, while prevalence of impaired kidney function was similar in both sexes (50\% each).

\section{CLINICAL CHARACTERISTICS}

The clinical characteristics of the study population are shown in Table 2.

Symptoms of fluid retention (facial and leg swelling) were significantly more common in patients with IKF. Urinary symptoms (polyuria, oliguria and nocturia), nausea and vomiting were also more common in patients with IKF than NKF patients, but the differences were not statistically significant. Heamaturia was present in $7.5 \%$ of patients with $\mathrm{NKF}$ and $1.7 \%$ of patients with IKF ( $\mathrm{p}=0.047)$.

Weakness of the body and pruritus occurred more often in patients with NKF than IKF; however the differences were not statistically significant ( $\mathrm{p}=0.071$ and 0.067 respectively).

Pallor was the most common clinical sign occurring in 32.5 and $40.2 \%$ of patients with $\mathrm{NKF}$ and IKF respectively; however the difference in prevalence was not significant $(p$ $=0.056)$.

Impaired conscious state, fluffy hair, and signs of fluid retention (facial puffiness, ascites and pedal oedema) occurred in $21.6 \%, 12.5 \%$, and $22.5 \%$ of patients with IKF and $2.5 \%, 7.5 \%$, and $7.5 \%$ of NKF patients respectively. The differences were statistically significant $(p=0.002,0.045$, and 0.032 ). The mean systolic and diastolic blood pressure were $115.33 \pm 17.17 \mathrm{mmHg}$ and $72.33 \pm 14.31 \mathrm{mmHg}$ for IKF patients, and $113.65 \pm 14.72 \mathrm{mmHg}$ and $73.24 \pm$ $11.86 \mathrm{mmHg}$ for patients with $\mathrm{NKF}(\mathrm{p}=0.600$ and 0.729 ) respectively. The body mass index $(\mathrm{BMI})$ was $20.19 \pm 4.31$ in IKF patients and $21.65 \pm 3.78$ in NKF patients $(p=0.065)$. The differences were not statistically significant.

\section{LABORATORY PARAMETERS}

The laboratory parameters of the study population are shown in Table 3.

The mean serum sodium, potassium and bicarbonate of patients with IKF and NKF were as documented in the table below. The differences were not statistically significant ( $\mathrm{p}=$ $0.766,0.966$ and 0.176 respectively).

The mean serum creatinine for patients with IKF and $\mathrm{NKF}$ was $284.96 \pm 342.41 \mathrm{umol} / 1$ and $86.82 \pm 15.09 \mathrm{umol} / 1$ respectively $(\mathrm{p}=<0.001)$. The mean serum urea for patients with IKF was $8.34 \pm 9.44 \mathrm{mmol} / 1$, and for patients with $\mathrm{NKF}$ was $3.04 \pm 1.44 \mathrm{mmol} / \mathrm{l}(\mathrm{p}=<0.001)$.

The mean GFR of patients with IKF and NKF was $52.49 \pm$ $34.49 \mathrm{ml} / \mathrm{min} / 1.73 \mathrm{~mm}^{2}$ and $95.23 \pm 21.45 \mathrm{ml} / \mathrm{min} / 1.73 \mathrm{~mm}^{2}$ respectively $(\mathrm{p}<0.001)$. The mean protein-creatinine ratio (PCR) was $1211.37 \pm 1451.63$, and $190.25 \pm 101.25$ for patients with IKF and NKF respectively $(p<0.001)$. The mean CD4 cell count of patients with IKF was $213.73 \pm$ 209.71/ul, and for patients with NKF was $318.75 \pm 248.40$ / $\mathrm{ul}(\mathrm{p}=0.019)$. The PCV for patients with IKF and patients with $\mathrm{NKF}$ was $29.49 \pm 7.92 \%$ and $36.39 \pm 8.32 \%$ respectively $(\mathrm{p}=<0.001)$

\section{DISCUSSION}

A large proportion (53.3\%) of HIV-infected patients studied had impaired kidney function defined as glomerular filtration rate less than $60 \mathrm{ml} /$ minute $1.73 \mathrm{~m}^{2}$ and/or daily urinary protein excretion of more than $200 \mathrm{mg}$. Previous studies have reported a lower prevalence rate of kidney disorder in HIV infection. ${ }^{5,8,9}$ The studies mentioned above excluded patients with low grade proteinuria as dipstick was the method used to assess proteinuria, and a study of population is developed with better socio-economic status and easier access to early diagnosis and treatment of HIV. However, Agaba et $\mathrm{al}^{7}$ in a study of HIV patients with renal disease in North Central Nigeria reported a prevalence rate of $52 \%$ which is consistent with results from this study.

HIV and renal disease have been respectively reported as diseases affecting young adults more than the other age groups in developing countries, $7,12,15$ and this trend is thought to be associated with poverty, low socio-economic status and higher sexual activity in the younger age groups. The majority $(89.8 \%)$ of HIV patients studied were younger than 50 years, in agreement with earlier reports. ${ }^{12,}{ }^{15}$ In consonance with an earlier report, females constituted a 
larger proportion $(58.5 \%)$ of the study population, and indeed females are more predisposed to HIV infection because of various social and anatomic make up traits that result in a higher prevalence of infection in them. ${ }^{16}$ However, despite a females' preponderance in this study population, $50 \%$ of patients with IKF were males, thus suggesting that renal disease is more common in the male gender. This is consistent with other studies. ${ }^{7,8,15}$

Various clinical features are common to both HIV infections and renal diseases. These features include easy fatiguability, weakness, anorexia, nausea, vomiting, change in bowel habit, pruritus, pallor, fluffy hair and weight loss. Hypertension and body swelling have been reported to be uncommon in HIV patients with renal disorder, especially in those with HIV-associated nephropathy. However, this study reported that fluid retention was more common in patients with IKF. This could have resulted from other comorbid conditions prevalent in these patients, including malnutrition, vasculopathy, hepatic or cardiac disorder, plus the fact that this study included patients with non-HIVAN kidneys disorders. Central nervous system manifestations were more common in patients with impaired kidney function in this study, which conforms to the fact that such features are commonly seen in HIV and CKD patients with co-morbidities/complications.

Anaemia is a common presentation in HIV infection and in patients with renal impairment. The co-existence of HIV infection and renal impairment worsens the burden of anaemia in these patients in terms of morbidity and mortality. ${ }^{17,}{ }^{18}$ Thus it is not surprising that anaemia in patients with IKF in this study was more severe. The causes of anaemia in both clinical conditions are multi-factorial and include malnutrition, haemolysis, haemorrhage, bone marrow suppression amongst others. The mean CD4 cell count in patients with IKF was lower than that in patients with normal kidney function, which is consistent with earlier reports of a positive correlation between prevalence/severity of renal disorder and CD 4 cell count. ${ }^{7,8,19}$ Immunosuppression, which is the hallmark of HIV infection, is also common in patients with IKF, thus HIV patients with IKF are more prone to infection which explains the higher white blood cell count in patients with IKF in this study.

There was no significant difference between the biochemical parameters of both groups in this study. However, serum creatinine and urea were higher, and the glomerular filteration rate lower in patients with impaired kidney function. Various electrolyte abnormalities, including hyponatraemia, hypokalaemia, hypouricaemia, hypocalcaemia, hypomagnesaemia, and acid/base imbalance, have been reported in HIV/AIDS patients. ${ }^{20-21}$

Proteinuria is an important parameter in the diagnosis and prognosis of kidney diseases. Nephrotic range proteinuria is part of the diagnostic criteria for renal diseases in HIV infection, especially in HIV-associated nephropathy (HIVAN). Proteinuria in this study was higher in patients with impaired kidney function but was not in the nephrotic range. This level of proteinuria may be due to the fact that some patients studied had other forms of renal disorder responsible for the impaired renal function.

In conclusion, impaired renal function is a common presentation in patients with HIV infection. HIV patients with impaired kidney function have poorer clinical, haematological and biochemical characteristics. Early detection of kidney disorder is imperative in HIV-infected patients; there is a need for screening of all HIV patients for renal function even at the time of diagnosis of HIV infection.

The limitations of this study include the small sample size and the fact that it is a cross-sectional study. There is need for a multi-centre cohort study to enable proper characterisation and identify the nature of impaired kidney function in HIV infected patients in developing countries.

\section{REFERENCES}

1. Weiner NJ, Goodman JW, Kimmel PL, The HIVassociated renal diseases: Current insight into pathogenesis and treatment, Kidney Int, 2002, 63:1618-1631.

2. Rao TKS, Fillipone EJ, Nicastri AD et al, Associated focal and segmental glomerulosclerosis in acquired immunodeficiency syndrome, N Engl J Med, 1984, 1631-45.

3. Winston JA, Klotman PE, Are we missing an epidemic of HIVAN?, J Am Soc Nephrol, 1996, 1:1-7.

4. Seney FD Jr, Burns DK, Silva FG, Acquired immunodeficiency syndrome and the kidney, Am J Kidney Dis, 1990, 16:1-13.

5. Winston JA, Klotman ME, Klotman PE, HIVassociated nephropathy is a late, not early, manifestation of HIV-1 infection, Kidney Int, 1999, 55:1036-1040.

6. Daugas E, Rouger JP, Hill G, HAART - related nephropathies in HIV-infected patients, Kidney Int, 2005, 67:393-403.

7. Agaba EI, Agaba PA, Sirisena ND, Antenyi EA, Idoko JA, Renal disease in AIDS patients in North Central Nigeria, Nig J Med, 2003, 12[3]:120-125.

8. Szczech LN, Gupta SK, Habash R et al, The clinical epidemiology and course of the spectrum of renal diseases associated with HIV infection, Kidney Int, 2004, 66:145152.

9. Nuermberger E, Concepts in HIVAN, The Hopkins HIV report,1999, 1-6. http://www.google.com July 2007.

10. Szczech LA, HIV related renal diseases, MedGen Med, 2005, 3:1.

11. Balow JE, Nephropathy in the context of HIV infection, Kidney Int, 2005, 67:1632-1633. 
12. Gerntholz TE, Goetsch SJW, Katz I, HIV-related nephropathy: A South African perspective, Kidney Int, 2006, 69:1885-91.

13. Valeri A, Neusy AJ, Acute and chronic renal disease in hospitalised AIDS patients, Clin Nephrol, 1991, 35[3]:110-8.

14. Rosenberg ZF, Fauci AS, The immunopathogenesis of HIV infection, Adv Immunol, 1989, 47:356-8.

15. Emem CP, Arogundade F, Sanusi A, Adelusola $\mathrm{K}$, Wokoma F, Akinsola A, Renal disease in HIVseropositive patients in Nigeria: An assessment of prevalence, clinical features and risk factors, Nephrol Dial Transplant, 2008, 23:741-746.

16. Onyemelukwe GC, Musa BOP, CD4/CD8 Lymphocytes / Clinical features of HIV seropositive Nigerians on presentations, Afr J Med Sci, 2002, 31:229233.

17. Okafor UH, Unuigbe EI, Wokoma FS, Spectrum of

\section{TABLE 1: AGE DISTRIBUTION OF SUB-} JECTS

\begin{tabular}{|l|l|l|l|}
\hline AGE (years) & $\begin{array}{l}\text { IKF } \\
\mathrm{N}(\%)\end{array}$ & $\begin{array}{l}\text { NKF } \\
\mathrm{N}(\%)\end{array}$ & $\begin{array}{l}\text { Total } \\
\mathrm{N}(\%)\end{array}$ \\
\hline$<20$ & $5(2.5 \%)$ & $5(2.8 \%)$ & $10(2.6 \%)$ \\
\hline $20-29$ & $46(22.5 \%)$ & $40(22.3 \%)$ & $86(22.5 \%)$ \\
\hline $30-39$ & $82(40.2 \%)$ & $67(37.4 \%)$ & $149(38.9 \%)$ \\
\hline $40-49$ & $54(26.5 \%)$ & $45(25.1 \%)$ & $99(25.8 \%)$ \\
\hline 50 and older & $17(8.3 \%)$ & $22(12.3 \%)$ & $39(10.2 \%)$ \\
\hline Total & $204(100 \%)$ & $179(100 \%)$ & $383(100 \%)$ \\
\hline
\end{tabular}

IKF (impaired kidney function), NKF (normal kidney function)

\section{FIGURE 1: SEX DISTRIBUTION OF STUDY POPULATION}

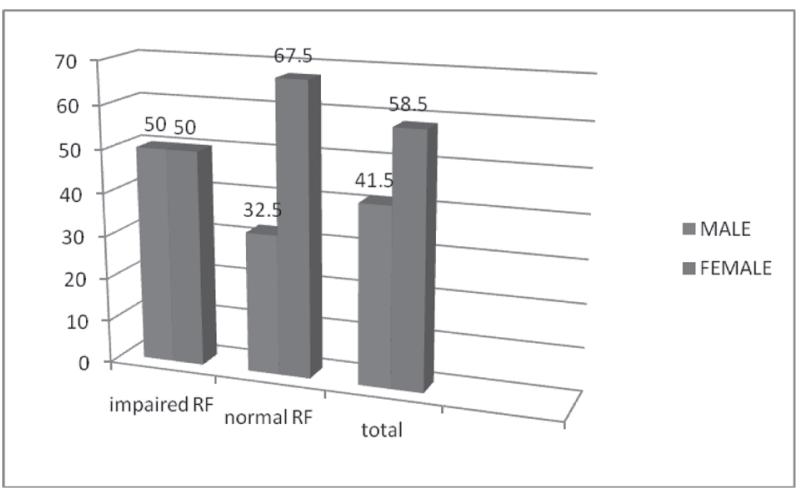

RF (kidney function) clinical presentations in human immunodeficiency virus (HIV) infected patients with renal disease, Afr J Infect Dis, 2011, 5(2):28-32.

18. Horwich TB, Fonarow GC, Hamilton MA, Mavlellan WR, Borenstein J, Anaemia is associated with worse symptoms, greater impairment of functional capacity and a significant increase in patients with advanced heart failure, J Am Coll Cardiol, 2002, 39:1780-1786.

19. Okafor UH, Unuigbe EI, Ojogwu I, Oviasu E, Wokoma FS, Renal disease in HIV-infected patients: What relationship with level of CD4 cell count, African Health Sciences, 2011, 11(S1):S28-S33.

20. Agarwal A, Soni A, Gechanowsky M, Chander P, Treser G, Hyponatraemia in patients with acquired immunodeficiency syndrome, Nephrol, 1989, 53(4):31721.

21. Earle KE, Senevivatue T, Shaker J, Shoback D, Fanconi's Syndrome in HIV-positive adults, J Bone Miner Res, 2004, 19(5):714-21.

\section{TABLE 2: CLINICAL CHARACTERISTICS OF THE STUDY POPULATION}

\begin{tabular}{|c|c|c|c|}
\hline $\begin{array}{l}\text { Clinical } \\
\text { features }\end{array}$ & IKF (\%) & NKF $(\%)$ & $\mathrm{P}$ value \\
\hline Weakness & $27.6 \%$ & $40.0 \%$ & 0.071 \\
\hline $\begin{array}{l}\text { Nausea/ } \\
\text { vomiting }\end{array}$ & $20.0 \%$ & $17.5 \%$ & 0.102 \\
\hline Pruritus & $11.6 \%$ & $30.0 \%$ & 0.067 \\
\hline $\begin{array}{l}\text { Symptoms of } \\
\text { fluid retention }\end{array}$ & $13.9 \%$ & $2.5 \%$ & $0.002 *$ \\
\hline $\begin{array}{l}\text { Urinary } \\
\text { symptoms }\end{array}$ & $9.4 \%$ & $8.3 \%$ & 0.071 \\
\hline Haematuria & $1.7 \%$ & $7.5 \%$ & $0.047^{*}$ \\
\hline Convulsion & $0.8 \%$ & $0.0 \%$ & $<0.001^{*}$ \\
\hline Pallor & $40.2 \%$ & $32.5 \%$ & 0.056 \\
\hline Fluffy hair & $12.5 \%$ & $7.5 \%$ & $0.045^{*}$ \\
\hline $\begin{array}{l}\text { Signs of fluid } \\
\text { retention }\end{array}$ & $22.5 \%$ & $7.5 \%$ & $0.032^{*}$ \\
\hline $\begin{array}{l}\text { Impaired } \\
\text { conscious state }\end{array}$ & $21.6 \%$ & $2.5 \%$ & $0.002^{*}$ \\
\hline $\begin{array}{l}\text { Mean systolic } \\
\text { BP (mmHg) }\end{array}$ & $\begin{array}{l}113.65 \pm \\
14.72\end{array}$ & $\begin{array}{l}115.33 \pm \\
17.17\end{array}$ & 0.600 \\
\hline $\begin{array}{l}\text { Mean diastolic } \\
\mathrm{BP}(\mathrm{mmHg})\end{array}$ & $\begin{array}{l}73.24 \pm \\
11.86\end{array}$ & $\begin{array}{l}72.33 \pm \\
14.31\end{array}$ & 0.729 \\
\hline Mean BMI & $\begin{array}{l}21.65 \pm \\
3.78\end{array}$ & $20.19 \pm 4.31$ & 0.065 \\
\hline
\end{tabular}

IKF (impaired kidney function), NKF (normal kidney function), BMI (body mass index) 
TABLE 3: LABORATORY PARAMETERS OF THE STUDY POPULATION

\begin{tabular}{|c|c|c|c|}
\hline Parameter & $\begin{array}{l}\text { Patients with IKF } \\
\text { (means } \pm \mathrm{SD} \text { ) }\end{array}$ & $\begin{array}{l}\text { Patients with NKF } \\
\text { (means } \pm \text { SD) }\end{array}$ & $\mathrm{P}$ value \\
\hline Serum sodium (mmo/l) & $135.50 \pm 11.25$ & $136.10 \pm 9.64$ & 0.766 \\
\hline Serum sotassium $(\mathrm{mmo} / \mathrm{l})$ & $4.16 \pm 0.88$ & $4.17 \pm 0.93$ & 0.966 \\
\hline Serum bicarbonate $(\mathrm{mmo} / \mathrm{l})$ & $21.97 \pm 5.64$ & $23.15 \pm 4.06$ & 0.176 \\
\hline Serum urea $(\mathrm{mmo} / \mathrm{l})$ & $8.34 \pm 9.44$ & $3.04 \pm 1.44$ & $<0.001 *$ \\
\hline Serum creatinine (umol/l) & $284.96 \pm 342.41$ & $86.82 \pm 15.09$ & $<0.001 *$ \\
\hline GFR $\left(\mathrm{ml} / \mathrm{min} / 1.73 \mathrm{~m}^{2}\right.$ & $52.49 \pm 34.49$ & $95.23 \pm 21.45$ & $<0.001 *$ \\
\hline PCR mg/g & $1211.37 \pm 1451.63$ & $187.25 \pm 168.01$ & $<0.001^{*}$ \\
\hline $\operatorname{PCV}(\%)$ & $29.49 \pm 7.92$ & $36.39 \pm 8.32$ & $<0.001 *$ \\
\hline WBC $\left(/ \mathrm{mm}^{3}\right)$ & $6535 \pm 4644$ & $5241 \pm 1776$ & $0.017^{*}$ \\
\hline CD4 cell count $(/ \mathrm{ul})$ & $213.71 \pm 209.71$ & $319.75 \pm 248.40$ & $0.019 *$ \\
\hline
\end{tabular}

IKF (impaired kidney function), NKF (normal kidney function), GFR (glomerular filtration rate), PCV (packed cell volume), WBC (white blood cell), PCR (protein creatinine ratio) 